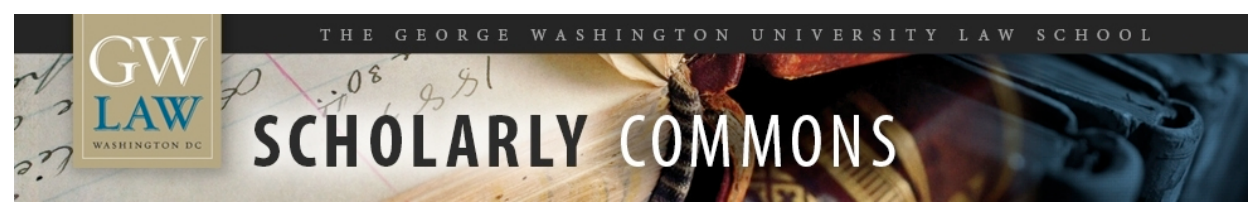

\title{
IP Transactions: On the Theory \& Practice of Commercializing Innovation
}

\author{
F. Scott Kieff \\ George Washington University Law School, skieff@law.gwu.edu
}

Follow this and additional works at: https://scholarship.law.gwu.edu/faculty_publications

Part of the Law Commons

\section{Recommended Citation}

F. Scott Kieff, IP Transactions: On the Theory \& Practice of Commercializing Innovation, 42 Hous. L. Rev. 727 (2005).

This Article is brought to you for free and open access by the Faculty Scholarship at Scholarly Commons. It has been accepted for inclusion in GW Law Faculty Publications \& Other Works by an authorized administrator of Scholarly Commons. For more information, please contact spagel@law.gwu.edu. 


\title{
ARTICLE
}

\section{IP TRANSACTIONS: \\ ON THE THEORY \& PRACTICE OF COMMERCIALIZING INNOVATION}

\author{
F. Scott Kieff *
}

\begin{abstract}
All too often within organizations and communities, innovations are not generated or put to use as rapidly or as broadly as they could be. Chief targets for blame include the problems of transaction costs, agency costs, lack of coordination, and improper incentives. Borrowing from the rich literature in the field generally known as new institutional economics, which has studied these types of problems more broadly, this Article elucidates how some practical tools might be expected to mitigate such problems. Particular arrangements of formal law and informal practice may help reach across the "valley of death" between early stage technologies and their downstream commercial deployment. Depending on the circumstances of a given situation, different practices and different aspects of the legal regimes of intellectual property, antitrust, business

* Associate Professor of Law, Washington University in St. Louis. The Author gratefully acknowledges financial support for this work from the 2003-04 and 2004-05 W. Glenn Campbell and Rita Ricardo-Campbell National Fellowships and Robert Eckles Swain National Fellowships at Stanford University's Hoover Institution, and from the law firm of Baker Botts. The Author also gratefully acknowledges intellectual contributions from participants in the Second Annual Baker Botts Lecture at the University of Houston Law Center on February 17, 2005, and appreciates helpful insights and comments provided by Steve Haber, Craig Joyce, John Norris, Troy Paredes, and Greg Vetter. Correspondence may be sent to fskieff.91@alum.mit.edu. JEL Classifications: A12, B15, B25, D23, D29, D61, K11, K20, K29, K39, O31, O33, O34.
\end{abstract}


associations, bankruptcy, property, and contract may prove most helpful. Elucidating at least as many questions for further empirical research as answers in the form of practical tips for structuring transactions, this Article focuses on the particular mechanisms by which the problems and proposed solutions might actually operate.

TABLE OF CONTENTS

I. INTRODUCTION 728

II. OVERVIEW OF THE NIE APPROACH 729

III. OVERVIEW OF NIE LESSONS FOR IP THEORY 732

IV. SOME IMPLICATIONS FROM NIE FOR IP PRACTICE AND EMPIRICAL RESEARCH.

A. Start-ups ................................................................... 743

B. Innovating Within Hierarchies .................................. 748

C. Deploying Research Tool Innovations...........................751

D. Bankruptcy.................................................................756

V. CONCLUSION

\section{INTRODUCTION}

Lawyers and other professionals may be seen as some of the giant transaction costs, or potential wastes, of modern society. ${ }^{1}$ Yet, in other respects, to the extent the underlying transactions themselves are good for society and to the extent lawyers facilitate those transactions, a positive view of lawyers is appropriate, championing their role as "transaction cost engineers."

1. See, e.g., Ronald J. Gilson, Seeking Competitive Bids Versus Pure Passivity in Tender Offer Defense, 35 STAN. L. REv. 51, 62-63 (1982) (noting that there are "two important elements of transaction costs in the acquisition setting: information costs necessary to identify the opportunity; and mechanical costs-for example, lawyers', accountants', and investment bankers' fees-necessary to effect the transaction and cope with regulatory or other barriers (including defensive tactics by the target)").

2. See, e.g., Ronald J. Gilson, Value Creation by Business Lawyers: Legal Skills and Asset Pricing, 94 YALE L.J. 239, 255 (1984) (describing lawyers as "transaction cost engineers"); Curtis J. Milhaupt \& Mark D. West, The Dark Side of Private Ordering: An Institutional and Empirical Analysis of Organized Crime, 67 U. CHI. L. REV. 41, 58 (2000) (borrowing Ronald Gilson's phrase "transaction cost engineers" to describe lawyers); Troy A. Paredes, A Systems Approach to Corporate Governance Reform: Why Importing U.S. Corporate Law Isn't the Answer, 45 WM. \& MARY L. REV. 1055, 1110-12 \& n.190 (2004) (examining Ronald Gilson's analytical framework of the lawyer as transaction cost 
Recognizing that a lawyer's real impact depends on the circumstances of a given situation, this Article focuses on the mechanisms by which particular types of transactions relating to intellectual property can be structured to best facilitate innovation and commercialization and explores both particular practice tips as well as topics ripe for empirical research. ${ }^{3}$ Touching on aspects of various legal institutions including intellectual property (IP), antitrust, business associations, bankruptcy, property, and contract, the Article proceeds as follows. Part II provides an overview of New Institutional Economics (NIE), the field of economics that studies the ways institutions impact economic performance in general. Part III provides a brief discussion of a role suggested by NIE for IP institutions in general and patent law in particular. Part IV explores some representative examples of transactions relating to IP for which insights from NIE can suggest both specific practice tools as well as topics for further empirical research. The Article considers particular transactional issues relating to one example from what may be seen as each phase of the commercialization business life cycle: start-ups, innovating within a hierarchy, deploying research tool innovations, and bankruptcy. Part V concludes.

\section{OVERVIEW OF THE NIE APPROACH}

NIE emphasizes the use of comparative institutional analyses to look at the different characteristics of institutions and what impact they have on individuals and organizations over time. ${ }^{4}$ The comparative institutional analysis approach of NIE

engineer); see also Lisa Bernstein, The Silicon Valley Lawyer as Transaction Cost Engineer?, 74 OR. L. REV. 239, 241-44 \& n.15 (1995) (exploring Gilson's analytical framework of the lawyer as transaction cost engineer and, in addition to Gilson, citing Lawrence M. Friedman et al., Law, Lawyers, and Legal Practice in Silicon Valley: A Preliminary Report, 64 IND. L.J. 555, 562 (1989) ("The Silicon Valley lawyer not only works with engineers, he thinks of himself as a kind of engineer-a legal engineer. ... $[\mathrm{H}]$ is job is to solve problems: to take a principle, a task and 'engineer' it legally ....")); Bernard Black \& Reinier Kraakman, A Self-Enforcing Model of Corporate Law, 109 HARV. L. REV. 1911, 1923 (1996) (pointing out that in addition to lawyers, "savvy investors and issuers" also help facilitate transactions).

3. The view offered here is rather optimistic about the role lawyers can play, although it is admittedly written from the perspective of one who is at least doubly biased on that point, as one who teaches lawyers and practiced law for several years.

4. The NIE approach treats as "institutions" the set of human imposed constraints-such as formal laws and rules and informal norms-and their enforcement characteristics. See Douglass C. North, Economic Performance Through Time, Nobel Lecture at Washington University (Dec. 9, 1993), in ECONOMIC SCIENCES 1991-1995, at 112-13 (Torsten Persson ed., 1997), available at http://www.nobel.se/economics/ laureates/1993/north-lecture.html (providing an overview of the field that is accessible to 
teaches us to ask not only what we want, but also which mix of formal and informal institutions will work better in achieving our set of goals. ${ }^{5}$

A core lesson of NIE is that even when there is consensus about what the goals of a particular institution should be, the particular choices that are made about the details of the institutional framework will have different and important implications for a number of problems operating on a number of levels. On the individual level, these problems include, inter alia, those of incentives, rent dissipation, information costs, and behavioralism. On the interpersonal level, these problems include, inter alia, those of transaction costs, agency costs, coordination, and private ordering. On the institutional level, these problems include, inter alia, enforceability of laws and norms, market failures, the differences between dynamic and static efficiency or between ex ante and ex post considerations, monopoly effects, government failures, and public choice, as well as public goods problems and the tragedies of the commons and anticommons. ${ }^{6}$

Because different institutional choices will have diverse implications-positive and negative-for these varied problems, NIE teaches why it makes sense as a conceptual matter to pay attention to means as well as ends. Engaging in a comparative institutional analysis makes conceptual sense because the perfect institution, like the perfect anything, is simply not achievable, and every real institution will have some problems. Accordingly, institutional choices should not be about a singular search for perfection but rather about which sets of problems and benefits

a general audience); see also MASAHIKO AOKI, TOWARD A COMPARATIVE INSTITUTIONAL ANALYSIS 3-5 (2001) (applying game theory to comparative institutional analysis and NIE to develop a deeper understanding of economic institutions); EIRIK G. FURUBOTN \& RUdOLF RICHTER, INSTITUTIONS AND ECONOMIC THEORY: THE CONTRIBUTION OF THE NEW INSTITUTIONAL ECONOMICS 6-7 (1997) (reviewing the concept of the institution and generally defining it to mean "a set of formal and informal rules, including their enforcement arrangements").

5. See FURUBOTN \& RICHTER, supra note 4, at 7, 18-19 (discussing the importance of both formal and informal institutions).

6. While these problems are grouped for presentation purposes here by the level at which they are most evident, and with the recognition that in some respect these groupings are inevitably imperfect, most of these problems can be seen to operate on more than one level. For a short and accessible overview of these various problems in the context of NIE, see Oliver E. Williamson, The Institutions of Governance, 88 AM. ECON. REV. 75 (1998) and Oliver E. Williamson, The New Institutional Economics: Taking Stock, Looking Ahead, 38 J. ECON. LITERATURE 595 (2000) (addressing the different levels of "social analysis"). See also FURUBOTN \& RICHTER, supra note 4, at 2-7, 122 (noting the "role of individual decision makers" and expounding on the various problems encountered at both the individual and institutional level). 
are best suited to tolerances and needs. Put differently, it is better to compare the particular costs and benefits of actually available options than merely to identify problems with one option and seek to perfect it. This is a theory of the "secondbest." The search for perfection is what Demsetz calls the "nirvana" fallacy, and as Voltaire noted, it is through such searches that "the perfect is the enemy of the good." This is not to say that institutions, existing or otherwise, should not be studied critically or that everything should be left alone because such complacency ignores the countervailing sage warning by John Dewey that "the better is too often the enemy of the still better." $" 10$

Moreover, institutions are essentially endogenous in that we can change them if we want. $^{11}$ Therefore, a comparative institutional analysis makes great sense as a practical matter as well. ${ }^{12}$

The comparative institutional analysis of NIE teaches a great deal about many institutions, including the institution of property in general and IP in particular. The section that follows

7. See FURUBOTN \& RICHTER, supra note 4, at 459 ("The basic conclusion, then, is that it is inappropriate to focus attention exclusively on hypothetical or 'ideal' solutions.... The implication is, of course, that relative to the idealized neoclassical benchmark all real-world situations can be no more tha[n] second best.").

8. Harold Demsetz, Information and Efficiency: Another Viewpoint, 12 J.L. \& ECON. 1, 1-2 (1969) (critiquing the so-called nirvana approach in favor of a comparative institution approach).

9. See The OXford Dictionary of Quotations 716 (Angela Partington ed., 4th ed. 1996) (translating the saying "le mieux est l'ennemi du bien" as meaning "[t]he best is the enemy of the good" and attributing the saying to Voltaire, Dictionnaire Philosophique (1770 ed.)).

10. Cass R. Sunstein, Free Speech Now, 59 U. CHI. L. REv. 255, 315 (1992) ("To the economists' plea that 'the perfect is the enemy of the good,' we might oppose Dewey's suggestion that 'the better is too often the enemy of the still better." (quoting 2 THE PHILOSOPHY OF JOHN DEWEY 652 (John J. McDermott ed., 1973)).

11. See FURUBOTN \& RICHTER, supra note 4, at 7 (explaining that an individual's self-interest can affect the functionality of institutions and that "endogenization of institutions is . . crucial to" NIE). The term "we" is used here in its broadest sense to refer to all people in general. However, even groups of people are often unable to effectively get particular government agencies or other institutions to fully incorporate their views. Indeed, this is one of the problems explored in NIE under the topic of "public choice."

12. Some institutions are harder to change than others. For example, rewriting statutes may not change the behavior of courts nor have the desired effect on norms. In the end, the best mix of institutions may depend in part on the institutions that are presently at play. Put differently, path dependency may also be relevant to the comparative institutional analysis. In addition, the field of NIE extends far into the realm of political science, where the process of institutional change is well studied. See, e.g., FURUBOTN \& RICHTER, supra note 4, at 23-24 (noting that any institution is susceptible to change and explaining the importance in understanding the causes and consequences of change). 
provides a brief overview of tips from NIE about an often overlooked role that IP can play.

\section{OVERVIEW OF NIE LESSONS FOR IP THEORY}

The bulk of law and economics literature on U.S. IP regimes focuses on a reward theory of patents, which is premised on a view that the government should first provide targeted incentives for specific, creative individuals to solve the public goods problem associated with intellectual works and then step in to mitigate the monopoly distortion and transaction costs associated with the IP right to exclude. ${ }^{13}$ The concern driving this perspective is that the subject matter protected by IP will be under-produced because, as characterized by the "Arrow Information Paradox," it has "public good" qualities. ${ }^{14}$ Under this view, incentives to

13. See, e.g., Clarisa Long, Information Costs in Patent and Copyright, 90 VA. L. REV. 465, 466 \& n.1 (2004) ("The conventional theory of intellectual property rights posits that such rights exist to stimulate the creation and distribution of intellectual goods." (citing Mark A. Lemley, The Economics of Improvement in Intellectual Property Law, 75 TEX. L. REv. 989, 993 (1997) ("Intellectual property [rights are] fundamentally about incentives to invent and create."))). Although there are a number of incentive-based theories for IP that are mentioned in the literature-including "incentive to invent," "incentive to disclose" or "teach," "incentive to innovate," and "incentive to design around"-there are essentially three dominant theories today: (1) some version of the "incentive to invent" and "disclose" theories treated together under the rubric of "reward"; (2) the "prospect" theory; and (3) the commercialization theory. See generally DonALD S. Chisum, Craig Allen Nard, Herbert F. Schwartz, Pauline Newman, \& F. Scott KIEFF, PRINCIPLES OF PATENT LAW 70-90 (2d ed. 2001) (reviewing various incentive theories for the patent system). See also Rebecca S. Eisenberg, Patents and the Progress of Science: Exclusive Rights and Experimental Use, 56 U. CHI. L. REV. 1017, 1024-46 (1989) (offering a slightly different take on various incentive theories of the patent system); A. Samuel Oddi, Un-Unified Economic Theories Of Patents-The Not-Quite-Holy Grail, 71 NOTRE DAME L. REV. 267, 273-89 (1996) (providing yet another slightly different take on various incentive theories of the patent system). For recent reviews of the copyright literature on incentive theories, see Glynn S. Lunney, Jr., Reexamining Copyright's Incentives-Access Paradigm, 49 VAND. L. REV. 483, 554-70 (1996), which suggests that incentives may draw efforts away from other productive activities. See generally Michael Abramowicz, Copyright Redundancy (Geo. Mason Univ. Sch. of Law, Law \& Econ. Working Paper Series, Paper No. 03-03, 2003), available at http://ssrn.com/abstract= 374580 (highlighting the opportunity cost issues discussed by Lunney as well as showing how additional works on the margin may contribute little while at the same time causing rent dissipation).

14. Kenneth Arrow described a paradox about information as follows: "its value for the purchaser is not known until he has the information, but then he has in effect acquired it without cost." KENNETH J. ARROW, Economic Welfare and the Allocation of Resources for Invention, in ESSAYS IN THE THEORY OF RISK-BEARING 144, 152 (1974) (discussing what has been called the "Arrow Information Paradox"). Certain goods in a market are said to be "public goods" if they have two distinctive features-they are nonrival and nonexclusive - that suggest they will tend to be under-produced, or not produced at all because of what some call a "free rider" problem. U.S. CONGRESS, OFF. OF TECH. ASSESSMENT, Finding A BALANCE: COMPUTER SOFTWARE, INTELLECTUAL PROPERTY AND THE Challenge of TECHNOLOGiCAl Change 185 (1992). 
produce are provided through specific rewards for specific creative work. For example, patents are offered as incentives to invent. Importantly, the literature does not see rewards merely as some kind of ancillary effect of IP; it sees rewards as IP's central goal. ${ }^{15}$ Further, under this view, the reward and its recipient must be carefully regulated to mitigate monopoly effects and transaction costs. ${ }^{16}$ As summarized by Jack Hirshleifer and John Riley when discussing patents, for example, "[t]he central problem considered by modern analysts... has been the conflict between the social goals of achieving efficient use of information once produced versus providing ideal motivation for production of information."17 Glynn Lunney has called this conflict or balance between incentive and access the "incentive access paradigm."

Although the reward literature contributes much to our understanding of IP, it has a number of serious limitations. One perspective is to see these theories as focusing on the role of government in providing both subsidy and regulation rather than providing what often are more predictable and less invasive forms of intervention, such as rulemaking and dispute resolution. That is, the government is seen as needed to support potential holders of IP and then to keep them in check.

Put simply, the reward theories may be viewed as premised on a false perception of tension between incentives and access. The inventive side of the paradigm is inapt because IP rights are not and should not be offered to provide direct incentives to invent or create. Similarly, the access side of the paradigm is also

Indeed, individuals have an incentive not to pay for the good, or to undervalue it, in hopes of getting access as "free riders." The inability to exclude free riders distorts market signals and is thought to result in inefficient allocation of resources to nonexclusive goods and underproduction of them, relative to socially optimal quantities.

Id.; see also MANCUR Olson, The Logic of Collective Action: Public Goods AND the THEORY OF GROUPS 43-52 (1971) (elucidating how small, defined groups are the most likely to overcome the transaction costs and free-rider problems raised by public goods).

15. See, e.g., Stanley M. Besen \& Leo J. Raskind, An Introduction to the Law and Economics of Intellectual Property, 5 J. ECON. PERSP. 3, 5-6, 8 (1991) ("The patent offers the incentive of the statutory right to exclude as a means for inducing creative activity.").

16. Several types of regulatory responses to IP rights are generally justified by this concern. Examples include, among others, liability rule treatment, misuse, and fair use.

17. J. Hirshleifer \& John G. Riley, The Analytics of Uncertainty and InformationAn Expository Survey, 17 J. ECON. LITERATURE 1375, 1404 (1979) (citing Kenneth Arrow, Economic Welfare and the Allocation of Resources for Invention, in THE RATE AND DireCtion of INVENTIVE ACTIVITY: ECONOMIC AND SOCIAL FACTORS 609 (1962), and Fritz Machlup, Patents, in 11 InTERNATIONAL ENCYClOPEDIA OF THE SOCIAL SCIENCES 461, 468 (David L. Sills ed., 1968)).

18. Lunney, supra note 13 , at $485-86$. 
inapt because by design IP rights are more successful than rewards in facilitating access.

Several fatal problems plague the reward theories of patents, which are premised on the concern that the subject matter of IP will be under-produced because as a public good it generates what some see as positive externalities for which payment cannot easily be gathered. First, as pointed out recently by Haddock, many such externalities turn out to be irrelevant because they are inframarginal. ${ }^{19}$ In other words, rewards may not be needed. Second, rewards may not be effective. ${ }^{20}$ Third, government grants of rewards can be fraught with negative side effects like rent seeking. ${ }^{21}$ Fourth, whether the reward is a patent or cash, there are a host of difficulties in developing a theory of just deserts as a basis for government allocation of any reward to potential claimants. ${ }^{22}$ But the most important limitation of the

19. David D. Haddock, Irrelevant Internalities, Irrelevant Externalities, and Irrelevant Anxieties 5-30 (Nw. Univ. Sch. of Law, Law \& Econ. Research Paper Series, Paper No. 03-16, 2003), available at http://papers.ssrn.com/abstract=437221 (providing examples and models of irrelevant externalities and citing James M. Buchanan \& Wm. Craig Stubblebine, Externality, 29 ECONOMICA 371, 374 (1962)). Consider for example, the pleasure a visually aesthetic garden brings to passersby who happen to see it, regardless of whether they contributed to its upkeep, the keeper of the garden has clearly managed to fund its creation and maintenance without reaping specific contributions from those passersby. For other examples of such irrelevant positive externalities see Jeffrey I. Bernstein \& M. Ishaq Nadiri, Interindustry $R \& D$ Spillovers, Rates of Return, and Production in High-Tech Industries, 78 AM. ECON. REV. 429, 429, 432-33 (1988), which found that, in recent years, social rates of return significantly exceeded private rates of return in five high-tech industries due to the benefit to other firms of research and development spillovers.

20. This may be because the activity is only responsive to alternative inducements such as self-satisfaction, search for knowledge, and reputation. See, e.g., Besen \& Raskind, supra note 15, at 6 .

Another critical element in deciding how to strike the balance between encouraging creativity and dissemination is the extent to which creative activity responds to economic rewards. The less that innovation depends on the resources invested and the potential economic rewards, the more limited is the case for granting substantial rights to creators.

Id.

21. See, e.g., JAMES M. Buchanan \& GORDON TUllock, The CAlCulus of CONSENT: LOGICAL FOUNDATIONS OF CONSTITUTIONAL DEMOCRACY (1962) (generally discussing how competition among those individuals seeking government benefits can cause society as a whole to invest more than those benefits are actually worth to society as a whole); James M. Buchanan, Rent Seeking and Profit Seeking, in TOWARD A THEORY OF THE RENT-SEEKING Society 7 (James M. Buchanan, Robert D. Tollison \& Gordon Tullock eds., 1980) (same).

22. See F. Scott Kieff, Property Rights and Property Rules for Commercializing Inventions, 85 MINN. L. REV. 697, 713-14, 714 n.77 (2001) (citing LEO KATZ, ILL-GOTTEN Gains: Evasion, BlackMaIL, AND KindRED PuZZLES OF THE LAW 200 (1996)). As pointed out when discussing the problem of two or more authors or inventors

[c]oncerning the distinction between acts and omissions, one might ask what level of contribution is required on the part of a supervising faculty member for 
reward theories, for purposes of the discussion here, is that by focusing on rewarding particular activities, these theories run the risk of overlooking some important insights revealed by NIE about the role property rights can play in facilitating coordination.

In contrast to the reward theories of patents, the commercialization theory sees patents as enforced by a property rule to help facilitate commercialization of the invention, after it has been made. ${ }^{23}$ The downstream commercialization requires coordination among the many complementary users of the patented invention, including, inter alia, developers, manufacturers, laborers, managers, investors, advertisers, and marketers. ${ }^{24}$ Providing a focal point, or beacon, ${ }^{25}$ the publicly recorded IP right helps each of these individuals find each other, ${ }^{26}$ and then by cracking the Arrow Information Paradox ${ }^{27}$ otherwise facing them, facilitates negotiations among them. ${ }^{28}$ At the same time, therefore, IP rights assist the creation and maintenance of both diversity and socialization among individuals within the market by providing the incentive and

co-authorship or co-inventorship. Is active advice required, or is passive permission and non-interference sufficient where others would have refused to allow or continue a project? Also consider how the rules of praise should evaluate the problems presented by cases of mere thought, transferred intent, or unreasonable hopes, any of which might nonetheless correlate with inventive success. To what extent should originality, effort, genius, or utility drive our decisions to allocate rewards?

Id. at $714 \mathrm{n} .77$ (citations omitted).

23. See id. at 710 (explaining how the "patent right to exclude competitors" aids in bringing all the players together to "facilitate commercialization of the patented invention").

24. Id. at 708-12 (discussing these many players and their incentives to interact).

25. While he initially saw property rights as tools for internalizing externalities, Demsetz's more recent work has focused on the role of property rights in facilitating coordination by serving this beacon function. See Harold Demsetz, Toward a Theory of Property Rights II: The Competition Between Private and Collective Ownership, $31 \mathrm{~J}$. LEGAL STUD. S653, S664-65 (2002) (claiming that specialization creates a need for coordination, which is facilitated by a private property system).

26. See F. Scott Kieff, The Case for Registering Patents and the Law and Economics of Present Patent-Obtaining Rules, 45 B.C. L. REV. 55, 99-100 (2003) (pointing out that the publicly recorded patent documents help coordinate commercialization by giving notice of the property right over which bargaining or avoidance can occur); $c f$. Richard A. Epstein, Notice and Freedom of Contract in the Law of Servitudes, 55 S. CAL. L. REV. 1353, 1354 (1982) (proposing "that under a unified theory of servitudes, the only need for public regulation, either judicial or legislative, is to provide notice by recordation of the interests privately created").

27. See supra note 14 (discussing Arrow's paradox).

28. See Kieff, supra note 22, at 710 (discussing the importance of the patent right, which encourages the "holder of the invention and the other players in this market to come together and incur all costs necessary to facilitate commercialization of the patented invention"). 
means for coordination among these diverse individuals. ${ }^{29}$ In addition, as elucidated by the registration component of the commercialization theory, the positive law rules for determining when a valid IP right may be obtained protect reasonable investment-backed expectations (and thereby decrease the risk of asset specific investments and opportunism) by making sure the right to exclude does not block activities individuals otherwise are doing or are about to do and by giving public notice of what is protected. ${ }^{30}$ Additionally, these positive law rules for obtaining patents do so with relatively low administrative and public choice costs. $^{31}$

The commercialization theory explores the comparative role of property rights in IP as a tool for facilitating the commercialization of the subject matter it protects. ${ }^{32}$ Under this view, IP offers a type of middle ground among several alternative institutional and organizational arrangements for facilitating

29. See John Joseph Wallis \& Douglass C. North, Measuring the Transaction Sector in the American Economy, 1870-1970, in LONG-TERM FACTORS IN AMERICAN ECONOMIC GROWTH 95 (Stanley L. Engerman \& Robert E. Gallman eds., 1986) (discussing the need for the government to establish and enforce a property rights system in order to promote productivity and lower costs of exchange within the context of a more general discussion of the connection between transaction costs and the division of labor). The connection between division of labor and transaction costs, including the inevitable limit that transaction costs places on the extent of the division of labor, was articulated by Adam Smith. See Harold Demsetz, The Cost of Transacting, 82 Q.J. ECON. 33, 35 (1968) (“'As it is the power of exchanging that gives occasion to the division of labour, so the extent of this division must always be limited by the extent of that power, or, in other words, by the extent of the market." (quoting Adam Smith)).

30. See Kieff, supra note 26, at 76-77 (pointing out that the prior art rules for patents protect "investment-backed expectations of both the patentee and its competitors ... in ways that involve" low administrative costs and in ways that make "sure that valid patents leave others free to do whatever they otherwise were doing"). That is, the novelty rules prevent patents from issuing on what others already are doing and the nonobviousness rules prevent patents from issuing on what others are about to do. $I d$. In addition, the disclosure rules operate to facilitate subsequent private ordering by giving public notice of the property rights. $I d$. at 99 . More specifically, the patent system operates using what is known as "peripheral claiming'-as distinct from 'central claiming'-in which the function of the patent claim is not to set forth the heart of the protected subject matter but rather to set forth its outer bounds." Id. at 109 .

31. Id. at 76. Indeed, because patentees are the lowest cost processors of the information needed to assess validity, information costs are mitigated when the property owners themselves are given such strong incentives to make these determinations. Recent empirical models suggest these incentives do work. As elucidated by Anderson and Hill, this type of owner-driven system for establishing property rights tailor-made to the needs of the owners is the best candidate for mitigating the rent-dissipation that otherwise can accompany the establishment of property rights. Terry L. Anderson \& Peter J. Hill, Privatizing the Commons: An Improvement?, 50 S. ECON. J. 438, 441, 443 (1983) (showing how less centralization in the definition and enforcement of property rights helps to improve efficiency by avoiding rent dissipation).

32. See Kieff, supra note 22 , at 707-11 (describing the roles and risks of inventors, capitalists, and other market players in bringing inventions to market). 
coordination among atomized individuals in the free market without IP rights, families or other close-knit groups, the firm, and the government. As a middle ground between a firm on one hand and a set of atomized individuals interacting across an open market on the other, property rights for IP can offer the coordination benefits of the firm and the strong incentives benefit of the market. ${ }^{33}$ At the same time, property rights for IP mitigate the risks of asset specificity and opportunism that are associated with full integration within a firm. Although integration within a firm is generally seen as decreasing certain problems of asset specificity and opportunism, ${ }^{34}$ property rights as an alternative to a firm may decrease other asset specificity and opportunism problems-for example, it can be easier for an inventor to walk away from a patent license with a firm than also to have to surrender a basic employment relationship with the firm. Property rights for IP also avoid the weakening of incentives associated with integration within a firm, and that can be especially pernicious where innovation is concerned. $^{35}$ In addition, property rights for IP can avoid the public choice costs of more substantial and direct government involvement by avoiding the need for a direct reward. Property rights also allow more open participation than families or other close-knit groups. $^{36}$ Given the availability of reasonably predictable enforcement through civil litigation backed by government courts, IP rights can facilitate private ordering through coordination without the need for the additional formal hierarchy associated with organizational structures of families, firms, or government agencies.

33. See R.H. Coase, The Nature of the Firm, 4 EconomicA 386, 393-96 (1937) (elucidating tension in the theory of the firm between transaction-cost avoidance and decreasing returns to management). Of course, property rights also offer some of the ill effects of each as well, including for example, some of the transaction costs of atomized individuals interacting across an open market.

34. See, e.g., Robert F. Freeland, Creating Holdup through Vertical Integration: Fisher Body Revisited, 43 J.L. \& ECON. 33, 34 (2000) ("The GM-Fisher case is . . . the most widely cited example of vertical integration reducing problems of physical and human asset specificity, and it serves as an empirical cornerstone for hold-up explanations of unified ownership."); see also R.H. Coase, The Acquisition of Fisher Body by General Motors, 43 J.L. \& ECON. 15, 18-19, 21-27 (2000) (reviewing facts of the GM-Fisher integration).

35. See Oliver E. Williamson, The Economic Institutions of CAPitalism 14142 (1985) (discussing the problem of weakened incentives within a firm and the particular problem this poses for innovation).

36. See Stephen Haber, Introduction to CRONY CAPITALISM AND ECONOMIC GROwTH IN LATIN AMERICA, at xii, xvi (Stephen Haber ed., 2002) (arguing that while close knit groups can bring the benefits of facilitating coordination, they also bring the costs of what Haber calls "crony capitalism"). 
Importantly, for private ordering to take place, liability rule treatment must be avoided. As recognized by Haddock, McChesney, and Speigel, the threat of the potential onslaught of "infringements induced by a liability rule will discourage investments" in the subject matter covered by the IP right ex ante, ${ }^{37}$ which will in turn diffuse the beacon effect otherwise associated with the right.

What is more, the monopoly impact of patents is both overstated and understated. Patented inventions face competition from prior, present, and future technologies. ${ }^{38}$ Furthermore, the ability to use price discrimination gives the patentee a strong financial incentive to maintain output at competitive levels, thereby avoiding the dead-weight loss potentially caused by a property owner's power over price. $^{39}$ Indeed, the 1980 changes in positive patent law in the biotechnology industry ${ }^{40}$ facilitated commercialization in that industry precisely because its commercialization costs were "characterized by a particularly large difference between average cost and marginal cost." ${ }^{41}$ The need for protection is especially strong in such markets because commercialization costs represent a significant component of average cost. ${ }^{42}$ Only in the United States, and only after this shift in positive law, has the private biotechnology sector included a constantly changing pool of around 1400 small and medium-sized companies, ${ }^{43}$ in addition

37. Kieff, supra note 22 , at $733 \&$ n.150 (stating that "the imposition of a liability rule may create a prisoner's dilemma in which each player's dominant strategy is to infringe in order to garner more of the potential gains from exchange for himself" and citing David D. Haddock et al., An Ordinary Economic Rationale for Extraordinary Legal Sanctions, 78 CAL. L. REV. 1, 16-17 (1990)).

38. Consider, for example, that aspirin, acetaminophen, ibuprofen, various steroids, and selective COX-2 inhibitors are each alternative technologies for treating pain.

39. Kieff, supra note 22, at 727-32 (showing how the patent system's facilitation of tie-ins and other forms of price discrimination where technological and economic factors alone might prevent price discrimination helps the patentee keep output at competitive levels).

40. Id. at $725-26,747$ (discussing such changes as the ability to patent living organisms and gene fragments).

41. Id. at 724-28, 747-48 (explaining that the average cost per unit of output includes both a pro rata share of total fixed costs, like the costs of building a factory, and marginal costs, which are the incremental costs of inputs like raw materials and labor that are needed to make each unit of output).

42. Id. at 724-25, 747 ("According to the commercialization view . . it is precisely this combination of high initial commercialization costs and risks facing the first mover and low marginal costs facing a second mover that makes the biotechnology industry a particularly strong candidate for patent protection.").

43. NIH: Moving Research from the Bench to the Bedside: Hearing Before the Subcomm. on Health of the H. Comm. on Energy and Commerce, 108th Cong. 47 (2003), available at http://energycommerce.house.gov/108/action/108-38.pdf (statement of Phyllis 
to those large firms (sometimes referred to as "big pharma") that were present in the United States and abroad both before and after the shift in positive law. Importantly, while access to finance and technology has increased within the United States and abroad during this same time, and while companies can be incorporated in the United States but still do business abroad and vice versa, this replenishing pool of market entrants is associated closely only with the availability of patents in biotechnology in the United States after $1980 .{ }^{45}$ In this regard, patents are associated with increased competition, not decreased competition. Put differently, not only do patents often fail to confer monopoly-like power, they can also be important antimonopoly weapons-their availability can serve as an effective antimonopoly vaccine for a market.

Concerns in the reward literature about behavioralism problems $^{46}$ are also misstated. More specifically, in response to concerns about behavioralism leading to failures in transactions

Gardner, Senior Associate Dean for Education and Student Affairs, Stanford University).

44. Id. at 49 (detailing the differences between the biotechnology industry and the pharmaceutical industry).

45. See F. Scott Kieff, Facilitating Scientific Research: Intellectual Property Rights and the Norms of Science-A Response to Rai and Eisenberg, 95 Nw. U. L. REV. 691, 70001 (2001) (noting "the [unique and] unmatched growth in the United States biotechnology industry and research since 1980" due in large part to positive patent protection changes made in 1980).

46. The term "behavioralism" refers to all of the ways in which human beings are not perfectly rational in decisionmaking and instead are said to be only "boundedly rational" in that they suffer, among others, cognitive biases and framing effects, and they employ heuristics. See Russell Korobkin, Bounded Rationality, Standard Form Contracts, and Unconscionability, 70 U. CHI. L. REV. 1203, 1206 (2003) (stating that "buyers are boundedly rational rather than fully rational descionmakers" and they only "take into account a limited number of product attributes and ignore others" when making purchasing decisions). Troy Paredes noted, "Explaining and understanding these deviations from perfect rationality make up the core of [the field known as] behavioral law and economics." Troy A. Paredes, Blinded by the Light: Information Overload and Its Consequences for Securities Regulation, 81 WASH. U. L.Q. 417, 444 n.125 (2003); see also Christine Jolls et al., A Behavioral Approach to Law and Economics, 50 STAN. L. REV. 1471, 1476-78 (1998) ("The task of behavioral law and economics ... is to explore the implications of actual (not hypothesized) human behavior for the law."); cf. GARY S. BECKER, Nobel Lecture: The Economic Way of Looking at Behavior, in THE ESSENCE OF BECKER 633, 650-51 (Ramón Febrero \& Pedro S. Schwartz eds., 1995) (stating that "[t]he rational choice model provides the most promising basis presently available for a unified approach to the analysis of the social world by scholars from different social sciences," including law). See generally Russell B. Korobkin \& Thomas S. Ulen, Law and Behavioral Science: Removing the Rationality Assumption from Law and Economics, 88 CAL. L. REV. 1051 (2000) (providing a "blueprint" for the "law-and-behavioral-science approach," which leads to a "more sophisticated understanding[] of both the ends of those governed by law and the means by which they attempt their ends" by relying on the psychological and sociocultural theories rather than just economics); Richard A. Posner, Rational Choice, Behavioral Economics, and the Law, 50 STAN. L. REV. 1551 (1998) (commenting on the behavioralism literature in general and in particular Jolls et al., supra). 
over IP rights, commentators have called for regulation of IP rights through the imposition of liability rule treatment and greater antitrust enforcement. ${ }^{47}$ To be sure, like all actors in the real world, IP owners are not perfectly rational. That is, people are only boundedly rational in that, among other things, they suffer cognitive biases and framing effects, and they employ heuristics. On the one hand, identification of behavioralism concerns does suggest reasons to be skeptical about the ability of individuals to actually achieve for themselves what is in their own best interest; as a result, behavioralism has justified resort to liability rules, regulation, immutable contract terms, et cetera. On the other hand, the individuals the government uses to affect these responses-legislators, regulators, and judges-are, of course, human beings too, and so also will suffer the limits of behavioralism. ${ }^{48}$ What is more, these government decisions will be subject to the public choice problems discussed below.

At bottom for IP, the behavioralism limits of the market are important costs to consider. To the extent the alternative to IP is simply lack of IP, then the countervailing considerations are the coordination benefits that the commercialization theory highlights. But to the extent regulation of IP is the alternative, then behavioralism limits for government actors associated with the regulation are also important countervailing considerations. Furthermore, to the extent the regulation will occur ex post, then interference with ex ante incentives is an additional countervailing consideration to letting behavioralism concerns justify deviation from basic property treatment for IP. Finally, as discussed more below, regulation brings with it the inevitable costs of government, including the tollbooth and rent-dissipation problems of agency capture, ${ }^{49}$ as well as the real concomitant problems alternatively known as "permit thickets," "License Raj," or "anticommons," as discussed more fully below.

Ironically, much of the recent literature advocating enhanced regulation of IP rights is tied to reliance on

47. See, e.g., Lemley, supra note 13, at 1048-72 (discussing the link between relaxing assumptions about rationality for IP and the use of liability rules for IP); see also Wendy J. Gordon, Asymmetric Market Failure and Prisoner's Dilemma in Intellectual Property, 17 U. DAYTON L. REV. 853, 857 (1992) (pointing out costs of rationality assumption).

48. See Paredes, supra note 46, at 434-44 (detailing countervailing behavioralism problems for government actors).

49. See Simeon Djankov, Rafael La Porta, Florencio Lopez-de-Silanes \& Andrei Shleifer, The Regulation of Entry, 117 Q.J. ECON. 1, 3 (2002) (defining "tollbooth" theory within the context of other theories of public regulation).

50. See infra note 58 and accompanying text (defining these concepts) 
anticommons concerns, ${ }^{51}$ but such reliance is misplaced for several reasons. In contrast to the real anticommons problem of the postsocialist economy, where an anticommons is correctly described, much of the private value that an IP owner obtains from the IP right to exclude is the ability to openly trade permission for use in exchange for money or other consideration. ${ }^{52}$ The economic motivations associated with such "residual claims" are precisely what mitigate anticommons concerns. ${ }^{53}$ As Richard Epstein and Bruce Kuhlik have recently pointed out in response to the perceived anticommons problem relating to IP, the distinguishing feature of the anticommons in the postsocialist economy is that the bureaucrats' efforts to openly trade their permission for personal gain are likely to trigger various forms of criminal liability for graft, bribery, and public corruption, among others. ${ }^{54}$ Indeed, even the potential for a

51. See, e.g., Michael A. Heller \& Rebecca S. Eisenberg, Can Patents Deter Innovation? The Anticommons in Biomedical Research, 280 SCIENCE 698, 698 (1998) (initiating literature on anticommons for IP within the context of biotechnology).

52. The IP owner may either actively license the IP to someone else who will in turn sell the subject matter protected by the IP, or the IP owner may sell the subject matter protected by the IP, which would include an implied license to the IP for its buyers. See F. Scott Kieff, Perusing Property Rights in DNA, in Perspectives on Properties of the HumAN GENOME PROJECT 125-28 (F. Scott Kieff ed., 2003) (explaining how patent rights can operate for biomedical discoveries including DNA); Kieff, supra note 45 (same).

53. See Anderson \& Hill, supra note 31, at 441-43 (using the term "residual claimant" while exploring the related problem of rent dissipation during races for a common prize); see also James M. Buchanan \& Yong J. Yoon, Symmetric Tragedies: Commons and Anticommons, 43 J.L. \& ECON. 1, 12 (2000) (highlighting the concern that the crux of the problem for both commons and anticommons relates to the ability of those engaged in the group activity to coordinate with each other, and that all other things being equal, the ability to coordinate is likely to be less the more the individuals have noneconomic motivations other than those enjoyed by individuals already otherwise within a close-knit community).

54. Richard A. Epstein \& Bruce N. Kuhlik, Navigating the Anticommons for Pharmaceutical Patents: Steady the Course on Hatch-Waxman 4 (Univ. Chi. Law \& Econ., Olin Working Paper No. 209, 2004), available at http://ssrn.com/abstract=536322 ("But the state bureaucrat is not the owner of any asset whose value will remain unlocked unless he brings it to market."). Nevertheless, individual regulators have incentives to try to extract such value, which explains the results of the empirical study of the public choice "tollbooth" theory of regulation elucidated by Fred McChesney, Hernando de Soto, and Andrei Shleifer, among others. See HeRnANDo DE Soto, The OTHER PATH: The INVISIBLE REVOLUTION IN THE THIRD WORLD (June Abbott trans., 1989) (discussing problems of corruption); JAMES GWARTNEY ET AL., ECONOMIC FREEDOM OF THE WORLD: 1975-1995, at 107-08 (1996) (providing a comparative study of the effects of reduced economic freedom on economic growth); FRED S. MCCHESNEY, Introduction to MONEY FOR Nothing: Politicians, REnT Extraction, AND Political Extortion 1-3 (1997) ("Rent extraction represents a conscious, welfare-maximizing strategy for politicians personally."); Djankov, La Porta, Lopez-de-Silanes \& Shleifer, supra note 49, at 3-4 (reporting empirical data showing existence and extent of the problem); Fred S. McChesney, Rent Extraction and Rent Creation in the Economic Theory of Regulation, 16 J. LEGAL STUD. 101 (1987) (elucidating that politicians and bureaucrats use legislation, regulation, and threats both to create rents and to extract them through campaign 
drive to suppress the subject matter protected by IP is mitigated by the uncertainty that higher untapped value may lie in wait. ${ }^{55}$ Put simply, the resulting social value of IP rights is that they encourage their owners to discover and market methods for pushing towards full competitive use levels; thus, IP rights will not create anticommons problems in biotechnology, software technology, or even in more mundane technologies like nails and screws. ${ }^{56}$

What is more, the reward literature on IP gets the concerns about anticommons backwards. Not only are anticommons problems for IP overstated, the response generated by these concerns-liability rule treatment and regulation-are likely to generate true anticommons problems. For example, the recent trend by the Federal Trade Commission and Department of Justice Antitrust Division to pursue actions against patentees on so-called "upstream" technologies in the name of mitigating problems of market power, transaction costs, and anticommons, is actually evidence of agency capture problems from the public choice literature that can only frustrate market entry and also upset private ordering overall because, as all players in the market realize over time, terms like "upstream" and "downstream" are so relative that they simply may be synonyms for "things to be bought" and "things to be sold" by any private party able to gain the agency's attention. ${ }^{57}$ Put simply, there is a huge difference between the openly tradable nature of property on the one hand and the pernicious permit thicket or License Raj on the other hand. ${ }^{58}$ At bottom, residual claim, tradability,

contributions, votes, political favors, or even bribes).

55. See Kieff, supra note 22 , at 726 (observing that commercialization risks and potential for future development provides incentives to license broadly).

56. See Kieff, supra note 52, at 127 (emphasizing that property rights will result in market participants bringing about the most efficient solution).

57. For an excellent and easily accessible review of such recent FTC activities, see Stanley M. Gorinson et al., Federal Antitrust Enforcers Focus on Intellectual Property Abuses, 10 InTEll. Prop. L. TODAY 38 (2003) (discussing Rambus and Unocal cases). For a more detailed discussion of the theoretical underpinnings of the problem with these actions, see F. Scott Kieff \& Troy A. Paredes, The Basics Matter: At the Periphery of Intellectual Property, 73 GEO. WASH. L. REV. 174 (2004).

58. See Sunita Parikh \& Barry R. Weingast, A Comparative Theory of Federalism: India, 83 VA. L. REV. 1593, 1608 (1997) (defining "License Raj" as a system in which centrally-appointed boards and agencies retain control over distribution of permits and licenses); Richard A. Epstein \& Bruce N. Kuhlik, Is There a Biomedical Anticommons?, REGUlation, Summer 2004, at 54, 55 (discussing permit thicket). These terms "permit thicket" and "License Raj" are more apt synonyms for the definition of anticommons that refers to the problem associated with hyper-proliferation of regulatory restrictions as compared with the broader definition of anticommons that refers to hyper-proliferation of property rights and that turns out not to be correct. For more on thicket-like problems of permits, see Richard A. Epstein, The Permit Power Meets the Constitution, 81 IowA L. 
enforceability, and private information are each reasons that IP rights are successful in avoiding anticommons effects.

\section{SOME IMPLICATIONS FROM NIE FOR IP PRACTICE AND EMPIRICAL RESEARCH}

The above account is offered only to provide, in a summary fashion, some of the theoretical reasons why treating IP as a property right protected by a property rule can facilitate the commercialization of innovations. The discussion that follows provides some representative examples of transactions relating to IP where some lessons from NIE about this coordination effect can suggest both specific practice tools and topics for further empirical research. These examples relate to transactional issues that arise in what may be seen as each phase of the commercialization business life cycle: start-ups, innovating within hierarchy, deploying research tool innovations, and bankruptcy.

\section{A. Start-ups}

Innovation is often associated with entrepreneurs, or startup companies. Usually characterized by limited resources, small size, and informal relationships among its participants, the startup business often faces a set of challenges relating to the seemingly harsh formalities of the legal and business environments. The singular drive to obtain financing, known as venture capital ${ }^{59}$ - either with an eye towards directly extracting value from that capital infusion or with an eye towards using it as a tool for facilitating further operation or developmentsometimes leads to decisions that do not adequately take into account the importance of the legal and business relationships being created.

REV. 407 (1995). This problem is not unique to the postsocialist economy and indeed is nicely captured by a well known expression used in India after throwing off British rule, also called "Raj," where it was said that Raj had been replaced by License Raj in the form of excessive and unpredictable requirements for permits and licenses from the many branches of the central government in order to conduct many important business activities. For more on the License Raj in India, see, for example, JAGDISH BHAGWATI, INDIA IN TRANSITION: FREEING THE ECONOMY 49-51 (1993) (discussing the system of permits and licenses needed in India for both outside investment and for internal economic development). See also Parikh \& Weingast, supra, at 1608. See generally M. Shahe Emran et al., After the "License Raj": Economic Liberalization and Aggregate Private Investment in India (Aug. 2003), http://ssrn.com/abstract=411080 (showing the effects of liberalization on the economy of India).

59. See ERIC S. Siegel et Al., The ERnst \& Young Business Plan Guide 22-25 ( $2 \mathrm{~d}$ ed. 1993) (discussing an overview of the details of venture capital). 
An often expressed fear about the start-up sector of the economy is that there exists a so-called "valley of death" between the start-up businesses with innovations on the one hand and the successful commercialization of their innovations on the other hand. ${ }^{60}$ What is interesting from an NIE perspective, is that the reason for this gap may be due more to institutions than to resources or information. More particularly, although those looking to obtain venture financing seem to offer attractive innovations in large numbers, those looking to invest in innovation seem to have large quantities of available resources, and the members of these groups seem to be meeting and interacting with each other, the rate of deals these two groups are able to achieve with each other may nevertheless be suboptimal.

A central problem may be that the legal and business relationships surrounding the innovation may not be designed ex ante with a sufficient eye towards the later stages of financing and its concomitant changes in ownership and control that so often have to occur. The problems may relate in some respects to IP law, or patent law, as well as to corporate law and contract law or more general problems of ownership and control.

Concerning IP law, the commercialization theory discussed earlier shows how important it is to have IP subject matter protected by a property right backed up by a property rule. It is the credible threat of an injunction that allows IP to serve as a coordination beacon around which all the potential complementary users of the asset it protects can gather. Several practical implications flow from this view, especially for the start-up company.

At the outset, effective patent protection must be sought. Two common pitfalls that must be avoided to ensure this result are: (1) delay in filing the application, and (2) reliance on anemic disclosures when filed.

Regarding timing, many countries treat any public use or sale of subject matter that later is the subject of a patent application as prior art that can destroy patentability of that subject matter. ${ }^{61}$ In contrast, the U.S. patent system allows a one year grace period under which public use or sale within one year

60. Darius Mahdjoubi, The Austin Information Industry: Across the Valley of Death (Feb. 2004) (unpublished slide presentation), http://www.bootstrapaustin.org/resources/ Valley_of_Death.pdf.

61. See, e.g., JosePh Straus, Grace PERIOD AND THE European AND International PATENT LAW 21-23 (2001) (analyzing European Patent Convention novelty provisions). 
of filing may not count as prior art. ${ }^{62} \mathrm{~A}$ cash constrained start-up eager to demonstrate or sell must be careful either to avoid public use or sale before filing or be certain to file within one year of any public use or sale.

An area of further inquiry therefore might be the impact of the grace period on start-ups. More particularly, it may be fruitful to explore the different mechanisms start-ups use to determine how to best strike the balance between the need to offer the invention for sale as a tool for raising financing and the need to maintain secrecy to preserve patent rights, as well as the consequences of these different approaches.

On the disclosure itself, an increasing number of Federal Circuit invalidity decisions have turned not on issues of prior art, but on issues of inadequate disclosure. ${ }^{63}$ Although preparing a detailed disclosure can be significantly more expensive, ${ }^{64}$ the penalty for insufficient disclosures may be a patent of zero value.

An area of further inquiry therefore might be the impact of initial disclosures on patent value. Specifically, it may be fruitful to explore the impact that initial costs for patent drafting and filing have on issued patent claims.

Even assuming a meaningful patent application has been filed in a timely fashion, it is essential to ensure that ownership of the application and any issued patents are concentrated and maintained in a single legal person (an actual life in being, or legal person such as a corporation or trust). Fragmentation of ownership poses a serious problem because it can create a tragedy of the commons in which the failure of a single owner to join in efforts to exclude potential infringers may lead to nonenforcement. ${ }^{65}$

62. 35 U.S.C. § 102(b) (2000); see also Baxter Int'l, Inc. v. COBE Labs., Inc., 88 F.3d 1054, 1058, 1060-61 (Fed. Cir. 1996) (holding that third party use may raise the statutory bar of $\S 102(b))$. Often described as a statutory bar to the patenting of inventions publicized for more than a year, this provision operates to provide a one-year grace period for publicity that will not bar patentability. The grace period first entered the U.S. patent system in 1839 as a period of "grace" lasting two years. Act of Mar. 3, 1839, ch. 88, 5 Stat. 354 (codified at 35 U.S.C. $\S 31$ ). The period was shortened to one year in 1939. Act of Aug. 5, 1939, ch. 450, 53 Stat. 1212 (amending 35 U.S.C. $§ 31$ (1934)). And it remains so in the present system. 35 U.S.C. $§ 102(b)$.

63. See, e.g., Gentry Gallery, Inc. v. Berkline Corp., 134 F.3d 1473, 1479-80 (Fed. Cir. 1998) (holding the disclosure for the particular patent to be insufficient); see also Univ. of Rochester v. G.D. Searle \& Co., 358 F.3d 916, 917 (Fed. Cir. 2004) (affirming summary judgment of invalidity for lack of sufficient disclosure).

64. See, e.g., Rick D. Nydegger, Practical and Legal Considerations in Drafting the U.S. Patent Application, in EleCtronic AND Computer Patent LaW 333, 365 (1990) (stating that a detailed patent disclosure can involve significant costs).

65. See Kieff, supra note 22, at 735 (citing ROBERT PATRICK MERGES, PATENT LAW AND POLICY 1228-36 (2d ed. 1997)). 
Because the touchstone of ownership for patents in the first instance is inventorship, assignments to a common single legal person must be obtained from all inventors. Before these assignments can be executed, each inventor must be identified. But care must be taken in tracking down all inventors because, as the statute makes clear, people may be joint inventors even though they do not physically work on the invention together, or work at the same time, or "make the same type or amount of contribution." ${ }^{\prime 66}$ And while the statute itself does not set forth the minimum quality or quantity of contribution required for joint inventorship, the Federal Circuit has stated that the test for inventorship may be easier to satisfy than some would expect: "[T]o be a joint inventor, an individual must make a contribution to the conception of the claimed invention that is not insignificant in quality, when that contribution is measured against the dimension of the full invention.." ${ }^{\prime 7}$ The Federal Circuit further noted, "Conception exists when a definite and permanent idea of an operative invention, including every feature of the subject matter sought to be patented, is known." ${ }^{\circ 8}$

A closely related problem to these patent law questions of inventorship and ownership are the questions of corporate law and contract law that often follow soon after the inventive entity situates itself within the start-up enterprise. The traditional notion associated with large publicly-traded corporations, that there is a separation between ownership and control, ${ }^{69}$ is less applicable to closely held corporations like start-ups. In close corporations, the same individuals frequently are shareholders, officers, and directors, ${ }^{70}$ which in turn means a decrease in specialization among the corporate team. While venture

66. 35 U.S.C. $\$ 116(2000)$.

67. Fina Oil \& Chem. Co. v. Ewen, 123 F.3d 1466, 1473 (Fed. Cir. 1997).

68. Sewall v. Walters, 21 F.3d 411, 415 (Fed. Cir. 1994).

69. See, e.g., Adolph A. Berle, JR. \& Gardiner C. Means, The Modern CORPORATION AND PRIVATE PROPERTY 69 (1932) (stating that for corporations, the gap between ownership and control is a "logical outcome of corporate development"). The efficiencies of the separation between ownership and control have long been recognized. See, e.g., Henry G. Manne, Our Two Corporation Systems: Law and Economics, 53 VA. L. REV. 259, 261-65 (1967) (stressing the efficiency of the specialization of function that characterizes the corporate form-wherein shareholders specialize in bearing risk and directors and officers specialize in managing the company).

70. See Nathalie Martin, Common-Law Bankruptcy Systems: Similarities and Differences, 11 AM. BANK. INST. L. REV. 367, 391 (2003) (stating that "there tends to be no difference between management and equity in the small firm"). Further, creditors of closely-held companies routinely contract around limited shareholder liability by demanding that the corporation's shareholders execute guarantees obligating them to satisfy the corporation's debts. Susan Kalinka, Shareholder Guarantees and Subchapter S Basis: Investment in the Corporation, 64 TEMP. L. REV. 659, 674 (1991). 
capitalists, of course, bring along the possibility of increased capital to a start-up venture, what many entrepreneurs in a close corporation seem to overlook is that these outsiders also bringeither directly themselves or through networks with other professionals - a vast amount of specialized skill and knowledge associated with the management and operation of a business, including expertise in phases of growth, economic markets, and regulatory regimes. ${ }^{71}$ The rub here is that unless the initial ownership and control norms and formal contractual relationships and other business organizational documents of the start-up are structured properly, start-ups may simply be ill suited for outside investment.

An area of further inquiry, therefore, might be the exploration of the exact nature and magnitude of the types of IP ownership and control problems that seem to be at play in the start-up sectors. For example, control might be too diffuse among the founders, resulting in a collective action problem in deciding how to approach venture financing. Or, control might be too concentrated in a founder who has esoteric interests that make venture sources wary of investing. For example, this control entity might care less than potential investors about financial return on investment. More pointedly, there may be a nontrivial risk that the control entity will develop, at best, totally orthogonal or, at worst, totally adverse interests to those of the venture capitalists. ${ }^{72}$

Finally, a related set of patent law and contract law problems of ownership and control arise as start-ups sometimes seek to out-license technology to more developed partners. Although it may initially seem that partnering with an established developer or manufacturer will maximize technology diffusion and absorption, that partner may shift agendas and lose interest in ensuring the use of the subject matter protected by

71. See David Gerhardt, Two Views of Venture Capital: The Entrepreneur, TEX. Bus. REV., Apr. 1999, at 4, 4 (noting that the best venture capitalists bring "business knowhow, industry expertise, and contacts" to their ventures).

72. This may be one of the reasons that some of the various government venture entities like In-Q-Tel and DeVinCi may not have as high of a success rate in commercialization as might have been hoped. It is difficult for these entities to bond themselves against the intense risks of large shifts in government policy that might make the entire business collapse. See Barry Ashby, Uncle Sam . . Venture Capitalist, InDUS. HEATING, Mar. 2005, available at http://www.industrialheating.com/CDA/ ArticleInformation/features/BNP_Features_Item/0,2832,146308,00.html (suggesting that government funds also involve conflicts of interest that lead to public policy making and result in "redistribution of risks to the public and reduced returns to the private investors"). 
the IP right. ${ }^{73}$ Although some might describe the scenario as patent suppression, in which the patent right to exclude use operates to prevent others from using while the licensee itself elects not to use, the term suppression implies a state of mind that may not always, or even often, be present. Yet, the problem can be avoided with careful contracting, including milestone requirements and the option to haul back technology and any related IP ownership or license if the technology is not sufficiently deployed.

An area of further inquiry, therefore, might be the exploration of the frequency and mechanisms by which such waste or suppression occurs, as well as the frequency of use and enforcement of milestone, haul-back, and other workaround clauses.

\section{B. Innovating Within Hierarchies}

Even after the start-up has been set up, it often must continue to innovate. Yet, the more the business entity grows, the greater the hierarchy and the greater the resulting problem, long recognized in the NIE literature, of innovating within hierarchies. Hierarchy is itself one of the core areas of study within the field of NIE. More particularly, the contrast between interactions among individuals through a market and interactions among individuals within a hierarchy such as a firm or government lies at the core of the early NIE literature by Coase on the theory of the firm. ${ }^{74}$ On the one hand, moving interactions within a hierarchy can avoid or mitigate many of those transaction costs associated with exchanges in the context of an open market. ${ }^{75}$ On the other hand, integration within a hierarchy has limits because of the decreasing returns to management due to several factors, including agency $\operatorname{costs}^{76}$ that

73. See Kieff, supra note 22, at 735 (noting that co-owners of a patent may lawfully grant licenses to third parties without accounting to the other co-owners, which may at least dilute the value of the patent overall and at most eliminate its value).

74. See generally Coase, supra note 33 (elucidating tension in the theory of the firm between transaction costs avoidance and decreasing returns to management). See also Ronald Coase, The New Institutional Economics, 88 AM. ECON. REV. 72 (1998) ("It is commonly said, and it may be true, that the new institutional economics started with my article 'The Nature of the firm' (1937) . ...").

75. See Coase, supra note 33, at 392 ("[T] $\quad$ he operation of a market costs something and by forming an organi[z]ation and allowing some authority (an 'entrepreneur') to direct the resources, certain marketing costs are saved.").

76. Michael C. Jensen \& William H. Meckling, Theory of the Firm: Managerial Behavior, Agency Costs and Ownership Structure, 3 J. Fin. ECON. 305, 308 (1976). The term "agency cost" generally refers to all the costs associated with the inevitable divergences in the interests among two individuals in situations in which one individual 
involve the agency relationship between owners and managers and the agency relationship between managers and labor. ${ }^{77}$

As demonstrated through models of both the private and academic sectors, agency problems can be particularly acute when the agent is tasked to innovate because the process of innovation is itself particularly fraught with uncertainty and because information about an innovator's efforts is likely to be especially asymmetrical as between a technologically trained innovator and a nontechnologically trained manager. ${ }^{78}$ To be sure, relational contracting, like that which occurs among individuals within a hierarchy, is just one typical form of incomplete contracting for which there are well-studied strategies to mitigate agency costs. ${ }^{79}$ One example of particular relevance to innovation would be the offering of stock options whose value presumably increases with the future profits

(the agent) acts on behalf of the other (the principal). As summarized by Jensen and Meckling:

The principal can limit divergences from his interest by establishing appropriate incentives for the agent and by incurring monitoring costs designed to limit the aberrant activities of the agent. In addition in some situations it will pay the agent to expend resources (bonding costs) to guarantee that he will not take certain actions which would harm the principal or to ensure that the principal will be compensated if he does take such actions.... In most agency relationships the principal and the agent will incur positive monitoring and bonding costs (non-pecuniary as well as pecuniary), and in addition there will be some divergence between the agent's decisions and those decisions which would maximize the welfare of the principal.

Id.

77. See generally FURUBOTN \& RICHTER, supra note 4, at 336-41 (discussing the limits of integration elucidated by WILLIAMSON, supra note 35, at 138-40).

78. See, e.g., Bengt Holmstrom, Agency Costs and Innovation, 12 J. Econ. BEHAV. \& ORG. 305 (1989) (modeling agency costs in innovation and identifying attributes that make it comparatively more difficult as a production activity in which to solve ordinary principal to agent problems compared to ordinary production processes because of greater ex ante uncertainty and asymmetrical information about the innovator's efforts); Wallace E. Huffman \& Richard E. Just, Setting Efficient Incentives for Agricultural Research: Lessons from Principal-Agent Theory, 82 AM. J. AGRIC. ECON. 828 (2000) (applying principal-agent theory to model different funding approaches for basic scientific research in the field of agriculture).

79. See, e.g., WILLIAMSON, supra note 35 , at $164-68$. Williamson notes the general importance of repeat play, reputation effects, and other private enforcement techniques he collectively calls "private ordering" as tools for mitigating problems such as agency costs and asset specificity. See id. at 164-67. For an excellent review of specific techniques corporations use to align incentives and remuneration with particular focus on their impact on chief executive officers, see Michael C. Jensen \& Kevin J. Murphy, Remuneration: Where We've Been, How We Got to Here, What are the Problems, and How to Fix Them (Harvard Bus. Sch., Research Paper No. 04-28, Eur. Corp. Governance Inst., Finance Working Paper No. 44/2004, 2004), available at http://ssrn.com/abstract=561305. For an overview of the theoretical underpinnings for these techniques and the problems they are designed to address, see George P. Baker et al., Compensation and Incentives: Practice vs. Theory, 43 J. FIN. 593 (1988). 
generated by a firm's innovations. Yet, the general uncertainty of allocating credit for innovation within a hierarchy combined with the problem of potential expropriation by control groups of the reward associated with innovation may operate synergistically to particularly impair incentives for innovation within a hierarchy. ${ }^{80}$

The specific incentives facing a potential innovator within a given hierarchy will likely vary across organizations and over time. ${ }^{81}$ As a result, the precise impact of a given incentive may not be predictable.

Because individuals have complex agendas, or preferences, and only limited resources available to use in achieving the diverse items on these agendas, they must, and do, make choices about which agenda items to pursue before others. The mechanisms by which individuals make choices have been studied in a variety of settings, and as Gary Becker concludes in his work extending economic analysis to new areas of human behavior and relations, "no approach of comparable generality has yet been developed that offers serious competition to rational choice theory." 82 But regardless of whether people are perfectly rational in making choices, they must and indeed do, make agenda-priority choices, at least implicitly. ${ }^{83}$ That is, without taking sides in the debate about whether rational choice theory fully captures the behavioralism models or whether they are appropriately considered somehow distinct, it is sufficient to point out that consideration of incentives, agendas, and resources does make sense because people really do consider them. As Becker, borrowing an aphorism from George Bernard Shaw, philosophized: "Economy is the art of making the most of life."”4

A given individual's agenda is likely to be complex and might, for example, include the goals of accruing money, fame,

80. FURUBOTN \& RICHTER, supra note 4, at 336-38 (highlighting Williamson's discussion of the problems of "causal ambiguity" and "general office intrusion" (expropriation) leading to impaired incentives to innovate).

81. See Williamson, supra note 35 , at 140 (stating that incentives facing a potential innovator will not be the same for every organization in every circumstance).

82. BECKER, supra note 46, at 650; see also Press Release: The Sveriges Riksbank (Bank of Sweden) Prize in Economic Sciences in Memory of Alfred Nobel for 1992 (Oct. 13, 1992), http://www.nobel.se/economics/laureates/1992/press.html [hereinafter Press Release] (describing the achievements and life work of Gary Becker).

83. See generally Korobkin \& Ulen, supra note 46, at 1066-74 (describing the limitations of rational choice theory, including its ineffectiveness at "yield[ing] a single, unique behavioral prediction... [and] fail[ing] to eliminate many conceivable possible actions").

84. See GARY S. BeCKer, The Economic Approach to Human Behavior, in THE ESSENCE OF BECKER, supra note 46, at 3 (quoting George Bernard Shaw); Press Release, supra note 82 . 
relaxation, or other things. Such an individual will regularly make decisions that effectively set priorities among these different goals. As some items on the agenda appear to that individual to be less likely to be achieved, the individual may tend to shift focus or reprioritize towards other items on the agenda. For instance, if it appears harder to obtain some hypothetical goal A than hypothetical goal $\mathrm{B}$, then investment in achieving A relative to $\mathrm{B}$ may decrease.

At bottom, the complex interaction among agendas, resources, information, and decisionmaking helps explain why actual incentive effects may be different than hypothesized. For example, paying potential inventors more per filed patent application may not be needed and may even lead to perverse incentives to file applications that are not worth their expense. This may lead to a tendency to instead try to peg bonuses for patents-either kudos or cash-to invention commercialization, but this too has problems. First, the uncertainty and delay in commercialization may substantially undercut its incentive effect. Second, personhood and other connections to the invention may provide sufficient bonding of interests. Put differently, the fear of gaming and too many applications may push reward to a later stage, but personhood concerns may dominate once an application is filed, so rewards then may not be needed and may trigger other costs. In the end, knowing the details of the institutional parameters at the local level will be the key. And, of course, a good manager can shape perception of both carrots (positive incentives) and sticks (negative incentives) by being a norm entrepreneur. One area for further empirical research on this issue, therefore, is to explore the types of norm structures and carrots and sticks that are found to work and not work for promoting innovation within hierarchies.

\section{Deploying Research Tool Innovations}

A topic of particular concern in the literature is tied to the problem of IP rights in basic research tools and their potential impact on subsequent innovation. However, the theoretical debates on this issue do not reveal the exact mechanisms by which actual successful and failed attempted exchanges are occurring.

Therefore, one area for further empirical research is to uncover data about actual behaviors in a community to better inform commentators, judges, and legislators about the role patents are actually playing in that community so that specific changes in laws and norms can be implemented where advisable. 
More specifically, one possible project could explore the objective and subjective parameters involved when members of the basic biological science community participate in attempted exchanges of material or information. The data generated will help policymakers shape laws, rules, and norms in order to best facilitate these essential exchanges. As recognized by the 2002 report published by the Organisation for Economic Co-operation and Development entitled "Genetic Inventions, Intellectual Property Rights and Licensing Practices," gathering this type of empirical data is a high priority in the field. ${ }^{85}$

Empirical projects focusing on related areas have been conducted, but while each has provided important information, none has generated broad-based data on the precise mechanisms associated with the actual attempted exchanges and the reasons they succeeded or failed. For example, the recent project by Walsh, Arora, and Cohen was based on a small sample set—only "70 interviews with IP attorneys, business managers, and scientists from 10 pharmaceutical firms and 15 biotech firms, as well as university researchers and technology transfer officers from 6 universities, patent lawyers, and government and trade association personnel." ${ }^{\prime 6}$ Additionally, the work by Hillgartner and Brandt-Rauf has provided specific examples of failed exchanges, which are essentially case studies. ${ }^{87}$ In another study, a group of researchers conducted a large-scale survey that focused on factors other than patents, including age, gender, and prestige of the scientist's host organization. ${ }^{88}$ While the foregoing examples have provided important insights by focusing on opinions, particular examples of failed exchanges, or the importance of factors other than patents, a large-scale survey of the actual way patents impact attempted exchanges remains to be conducted.

The basic proposal offered here is to conduct a survey of members of the basic biological science community designed to

85. See, e.g., ORg. For Econ. Co-Operation And Dev., Genetic Inventions, INTELLECTUAL PROPERTY RightS AND LICENSING PRACTICES 83 (2002), http://www.oecd. org/dataoecd/42/21/2491084.pdf (listing this need for empirical data first among a set of priorities).

86. John P. Walsh et al., Research Tool Patenting and Licensing and Biomedical Innovation 8 (Carnegie Mellon Heinz Sch., Working Paper No. 2003-2, 2002), http://www. heinz.cmu.edu/wpapers/retrievePDF?id=2003-2.

87. Stephen Hilgartner \& Sherry I. Brandt-Rauf, Data Access, Ownership, and Control: Toward Empirical Studies of Access Practices, 15 KNOWLEDGE 355, 359, 363-66 (1994) (discussing "data stream" theory of data sharing and barriers to data access in academic research).

88. Eric G. Campbell et al., Data Withholding in Academic Genetics: Evidence From a National Survey, 287 JAMA 473 (2002). 
generate different types of data about the objective and subjective parameters involved when members of the biological science community participate in exchanges of material or information. One series of questions should be directed to personal, but not private, characteristics of the individual participants-such as gender, seniority, participation on peer review and promotions committees, and views about how patents can and should operate in this field. Another series of questions should be directed to the characteristics of the host institutions involved in the attempted exchanges-such as whether they are commercial, educational, or governmental and whether they receive funding from sources that are commercial, educational, or governmental. The next series of questions should be directed to the characteristics of the attempted exchanges themselves-such as whether negotiations were conducted directly by the scientists themselves, by administrative personnel, or by attorneys; whether they were between individuals who participated in prior exchanges or who expect to partake in future exchanges; whether they were conducted in writing, via e-mail, by phone, or in person; whether they were perceived as easy or difficult; and whether they were based on form documents or generated during negotiations. An additional series of questions should be directed to the results and impact of the attempted exchanges-such as whether the exchange was consummated and if it was, whether consummation occurred in time to be helpful to the requester and whether the requester retrospectively viewed the price paid as too high; but if it was not consummated, whether nonconsummation impacted the requester's work, whether the exchange failed because the requester viewed the price demanded or hassle of negotiation as too high, and whether as a result of the attempted exchange the participant is more or less likely to initiate or respond to a subsequent request for exchange.

The data from this project will provide the first empirical evidence about the frequency and mechanisms of exchange failure and consummation relating to the use of patents in the basic biological research community so as to provide essential empirical evidence to help resolve the policy debate between patent critic and patent proponent theories. If a high rate of consummation is found, it will provide one reason why the community has enjoyed such great success since $1980{ }^{89}$ Conversely, if a low rate of consummation is found, it may suggest that such success could have been even greater, and that

89. See supra note 45 (noting the expansive growth of the U.S. biotechnology community after 1980). 
the community might be expected to experience a lower rate of success in the future when research will be building upon the more foundational work from the period of initial development in this relatively new field.

Perhaps more importantly, the data from this project will provide the first empirical evidence about the different types of market failures that might be occurring in the basic biological science community. This is important because different types of failure may suggest different policy responses.

Some failures that might be occurring may suggest the need for the development of new institutional approaches. It may turn out that the individual hassle costs of dealing meaningfully with attempted exchange in each case are experienced by members of the community in much the same way we all experience the hassle costs of telemarketing for goods or services that actually are better deals than those we are presently using, and yet we rationally elect in each case to simply not reply. In such a case, one appropriate policy response would be the establishment of a new institution to facilitate exchanges using standardized terms, like a clearing house analogous to the artist rights groups-the American Society of Composers, Authors and Publishers (ASCAP) and Broadcast Music, Incorporated (BMI)—in the music industry ${ }^{90}$ or the Copyright Clearance Center's on-line catalog for permission to photocopy published texts. ${ }^{91}$

Other failures may suggest the need for legal reform. The fear of liability for patent infringement could be keeping many researchers from gaining access to needed materials and techniques. One response to such concerns that has been adopted in the regime of copyright law is to change patent law to permit a form of research fair use or pro bono publico exemption. ${ }^{92}$

A related concern may be that such perceptions about liability, even under existing patent law, may be misinformed because those who engage in activities without permission from the patentee may not be suffering repercussions. That is, the patentees may actually be granting what in effect is an implied license for such activities. ${ }^{93}$ In such a case, some failures that

90. See William M. Landes, Copyright, Borrowed Images, and Appropriation Art: An Economic Approach, 9 GEO. MASON L. REV. 1, 7 n.18 (2000) (discussing artist rights groups in the entertainment industry).

91. Copyright Clearance Center, http://www.copyright.com (last visited Oct. 2, 2005).

92. See Craig Joyce, "A Curious Chapter in the History of Judicature": Wheaton v. Peters and the Rest of the Story (of Copyright in the New Republic), 42 Hous. L. REv. 325, $390 \mathrm{nn} .296-97$ (2005) (discussing noninfringing uses of copyrighted material).

93. See e.g., Anton/Bauer, Inc. v. Pag, Ltd., 329 F.3d 1343, 1350 (Fed. Cir. 2003) 
might be occurring may be due to a misunderstanding among members of the community about how patenting actually operates. For example, some community members might be seeking and enforcing patents that would not be viewed as profitable to a rational, well-informed actor and some members might be seeking express permission that might not be worth obtaining to a rational, well-informed actor. In such cases, an appropriate policy response would be the creation of new educational programs about how individual members of the community could get the most out of the patent system in a way that also will provide net benefits for the community. For example, some universities, such as the Massachusetts Institute of Technology, have developed patent acquisition and technology transfer practices that tend to maintain the tightest private control over the inventions that can be used most efficiently from a societal point of view if subject to a single rights-holder. ${ }^{94}$ This behavior is in the commercial self-interest of the individual university because obtaining and enforcing patents in this area is an extremely expensive and risky investment. Such behavior offers a possible model of a new descriptive norm among individual actors in the community acting rationally within their own self-interest to maintain the tightest private control over only those inventions that can be most efficiently utilized if subject to a single rights-holder. Such a model also will avoid frustration of the consensus set of abstract prescriptive norms.

The data generated by this project will provide the first empirical evidence available for use in running established economic models of exchanges among market actors, in general, to evaluate how successful such attempted transactions actually are when they occur among members of the basic biological science community, in particular. These models teach that such transactions are likely to fail when, all things considered, the transaction costs themselves exceed the perceived potential gains from the trade. This can occur in many situations, such as when there are information asymmetries, cognitive biases, holdouts, and other market failures. These models also teach that markets that are thinner, in that they are less diverse and less wealthy, tend to experience these market failures more often and with greater negative impact than other markets. Therefore, this

(explaining that a "patentee grants an implied license to a purchaser when (1) the patentee sells an article that has no noninfringing uses and (2) the circumstances of the sale plainly indicate that the grant of a license should be inferred").

94. Arti Kaur Rai, Regulating Scientific Research: Intellectual Property Rights and the Norms of Science, 94 Nw. U. L. REV. 77, 144-46 (1999) (noting such practices are efficient); $i d$. at 110 (describing Massachusetts Institute of Technology's licensing program). 
project can help policymakers use established techniques in other fields to shape laws, rules, and norms so as to best facilitate exchanges in the important field of basic biological research.

\section{Bankruptcy}

Although the topic of bankruptcy may seem rather gloomy, especially so soon after the upbeat topic of start-ups, the reality is that the threat of bankruptcy is omnipresent. Yet, the question of control rights in bankruptcy is especially important when it comes to IP:

Tangible assets generally retain their value both during and after bankruptcy proceedings .... [But] IP is different. IP rights are typically most valuable when they carry a credible threat of injunction. However, as a result of the delay and coordination problems inherent in the bankruptcy system, a debtor's IP rights may be underenforced against infringers.... Consequently, the bankruptcy process itself potentially can eliminate all, or at least a substantial portion, of the value of IP rights.

To ensure that a debtor's IP rights are enforced vigorously, a party with the right incentives, information, and resources, as well as with standing to sue, needs control over IP assets in bankruptcy. Some might suggest that modern bankruptcy practice already has become, or is increasingly becoming, sufficiently streamlined so that the delay and coordination problems of the bankruptcy process do not present serious concerns for the enforcement of IP rights. However, the extent of the impact that such procedural improvements might have on ensuring the value of IP rights in bankruptcy is debatable. ${ }^{95}$

In response to this concern, the practitioner might offer a bankruptcy remote special purpose entity ("SPE") to hold title to IP assets in a move that is not unlike a typical asset securitization. ${ }^{96}$

It is recognized that the creation of an IP-SPE imposes its own risks and costs. For example, the transfer must be a true sale, the costs of the transaction itself will not be trivial, and control over the SPE must be agreed upon.

Therefore, one area for further empirical research on this issue is to explore the types of IP-SPEs that are used and under

95. F. Scott Kieff \& Troy A. Paredes, An Approach to Intellectual Property, Bankruptcy, and Corporate Control, 82 WASH. U. L.Q. 1313, 1315-16 (2004) (footnotes omitted).

96. See id. at 1316-17 (exploring IP-SPE within the context of bankruptcy). 
what circumstances they are used. Related empirical research could also indicate the extent to which failure to rely on the IPSPE approach results in any real problem in the first place:

We recognize that more needs to be known about the extent to which the problems discussed above are not only problems in theory but problems that actually occur in the real world. Informal observations of practitioners reveal that while some lawyers and their clients spend substantial resources structuring IP transactions around the types of bankruptcy concerns described above, others do not. In other words, even if the costs that bankruptcy poses for IP are not large on the whole, they do exist and are thus relevant to any consideration of the implications of bankruptcy for IP assets. To gain a richer understanding of the nature and extent of the problems bankruptcy poses for IP, it would be worth studying empirically specific disputes and transactions. For example, it would be helpful to understand better the extent to which bankruptcy increases infringement of debtors' IP rights. Better information regarding how often, and under what circumstances, a debtor-in-possession or trustee-in-bankruptcy actually fails to bring and aggressively pursue infringement actions also would be useful. Relatedly, one could explore which corporate constituencies of a debtor instigate the bringing of infringement actions and how other constituencies react when an infringement action is urged. In particular, it would be useful to know more about the precise mechanisms by which efforts to enforce or transact over an IP asset that is part of a bankruptcy estate actually occur, including how such efforts are mounted and by what parties, how other constituencies respond and why, and what specific factors influence how these efforts play out. Further, it is important to have more systematic data regarding how often the defenses of laches, estoppel, and implied license are asserted by an alleged infringer against an IP right that has been tied up as part of a debtor's bankruptcy estate and under what circumstances the defenses are successful. Finally, one could collect data concerning the extent to which parties shy away from entering into licensing arrangements with a debtor in bankruptcy or even with a company that is not yet bankrupt but that is financially distressed. ${ }^{97}$

In addition, it also would be interesting to determine "how frequently, and under what circumstances, disputes arise over whether the efforts of a debtor-in-possession or trustee-in- 
bankruptcy to enforce or transact over IP rights falls within the scope of the ordinary course of business." 98

\section{CONCLUSION}

How best to facilitate the processes by which ideas become inventions and inventions become useful products or processes is a question of importance to members of the government, academic, and private sectors. These processes matter to all those wishing to use technology, invest in it, trade in it, or benefit from its overall impact on national economic development, on international economic competitiveness, and on other noneconomic public policy goals. Yet, many ideas fail to become inventions as rapidly as possible, and many inventions fail to be commercialized as broadly or as rapidly as possible. Put simply, the generation and deployment of innovation within organizations, markets, and communities too often fails to occur at levels and timing we might prefer.

This Article explores how some particular arrangements of formal law and informal practice may help reach across the "valley of death" between early stage technologies and their downstream commercial deployment. Recognizing that a lawyer's real impact of course depends on the circumstances of a given situation, this Article focuses on the mechanisms by which particular types of transactions relating to IP can be structured to best facilitate commercialization of innovations. Recognizing that in different situations, different circumstances may suggest different approaches, particular practice tips and particular topics ripe for empirical research are identified in a few representative areas relating to innovation: start-ups, innovating within hierarchy, deploying research tool innovations, and bankruptcy. It is hoped the ideas explored here will help practicing lawyers continue to best fulfill their role as transaction cost engineers, while at the same time helping academics and policymakers identify those areas where further empirical research is needed.

98. Id. at 1329 n.51. 